\title{
CONCENTRATION OF LEAD, CADMIUM, AND IRON IN SEDIMENT DUST AND TOTAL SUSPENDED PARTICLES BEFORE AND AFTER INITIALISATION OF INTEGRAL PRODUCTION IN IRON AND STEEL WORK PLANT ZENICA*
}

\author{
Halim PRCANOVIĆ, Mirnes DURAKOVIĆ, and Sanela BEGANOVIĆ \\ University of Zenica, Metallurgical Institute Kemal Kapetanović, Zenica, \\ Bosnia and Herzegovina \\ Received in December 2011 \\ CrossChecked in January 2012 \\ Accepted in May 2012
}

\begin{abstract}
Poor air quality is a common fact for all areas with base industry. The city of Zenica was once the metallurgical centre of Ex-Yugoslavia and is therefore highly polluted at present. Air pollution peaked in 1987 when average concentration of pollutants was extremely high (daily average concentration of $\mathrm{SO}_{2}$ was $1800 \mu \mathrm{g} \mathrm{m}^{-3}$ ). With the beginning of the war in 1992, integral production in the steel work plant was shut down, to be re-launched in 2008. Limit values for iron do not exist, but iron has been monitored in Zenica for the past 28 years because of the presence of steel works. Concentrations of cadmium and lead have also been measured because they are very much present in polluted areas with steel works. The concentration of mentioned elements in air deposit and total suspended particles before and after integral production in the steel work plant was re-launched is the subject of this paper. Total suspended particles were measured in two locations using German standard VDI 2463 Blatt 4. Sediment dust was measured in nine locations using Bergerhoff method. The concentration of iron, lead, and cadmium was performed in the chemical laboratory of the Metallurgical Institute "Kemal Kapetanović" Zenica using standard methods. Higher concentrations of these parameters during the period of integral production clearly point to the impact of steel works on Zenica valley.
\end{abstract}

KEY WORDS: air pollution, atmospheric dust, temperature inversion, Zenica

Air quality was and still is the subject of many research studies. Because of a large number of industrial sources of pollution, ambient air in the city of Zenica is very highly polluted. This problem deteriorates in winter because of the heating season and temperature inversion, which impedes dispersion of pollutants $(1,2)$. When analysing air quality

* Partly presented at the $7^{\text {th }}$ Croatian Scientific and Professional Assembly “Air Protection '11" in Šibenik, Croatia, 13-17 September 2011 measurements performed in the past decades, one can conclude that metrological conditions have changed: periods with inverse layers of atmosphere have become longer. For example, in December 1989, there was a period with temperature inversion of about 10 days, during which daily average concentration of $\mathrm{SO}_{2}$ reached the value of $1800 \mu \mathrm{g} \mathrm{m}^{-3}$ (3). This occurred again in December 2007, when the period with temperature inversion lasted for about 7 days, and daily average concentration of $\mathrm{SO}_{2}$ reached the value 
of $900 \mu \mathrm{g} \mathrm{m}^{-3}$ (3). Highly polluted ambient air in Zenica district compelled local companies to assess the impact of their sources of pollution on air quality. Following this line of reasoning, Steel Works Zenica, the biggest air polluter in the area, developed an impact study in which it looked into its main sources of air pollution with sulphur dioxide. The study showed that under the conditions of low dispersion (winter period - inverse layers of atmosphere), these sources had no major impact on air quality in the city of Zenica thanks to their high chimneys (4). A much bigger problem were industrial sources with low chimneys, house stows, boilers in small factories, steam locomotives, and vehicles. This study can be confirmed with the daily average concentration of $900 \mu \mathrm{g} \mathrm{m}^{-3} \mathrm{SO}_{2}$ measured in December 2007, at a time when Steel Works Zenica had no integral production. Integral production is characterised by a network of interdependent material and energy flows between various production units (sinter or pelletisation plant, blast furnace, coke oven plant, basic oxygen furnace plant or electric arc furnace plant with subsequent casting). Blast furnace is the main operational unit with primary reduction of oxide ores leading to liquid iron. Sinter or pelletisation is a process of preparation of blast furnace charge, which involves agglomeration of blast furnace burden. Essentially this is a physical and metallurgical preparation of blast furnace burden, which improves permeability and reducibility. Coke oven is a production unit which produces coke from coal by means of dry distillation. Coke has better chemical and physical characteristics than coal. Basic oxygen furnace is a unit where carbon content of liquid iron is lowered to less than $1 \%$, thereby resulting in steel. Electric arc furnace is a production unit in which direct smelting of materials containing iron is performed. High voltage electric arc is used for smelting materials.

When we consider metal in total suspended particles (TSPs) and in sediment dust (SD), the situation is not flattering for the city, especially for the areas around Steel Works Zenica. This is because TSPs and SD contain a lot of heavy fractions which literally "cross the fence" of Steel Works.

In order to determine air quality in the city of Zenica, Metallurgical Institute has been performing measurements of air quality for more than 20 years. Air pollution is determined by measuring the concentration of sulphur dioxide, total suspended particles, and suspended dust, as well as by measuring the concentration of metals in total suspended particles and in sediment dust. Air quality measurements used to be performed quite intensively before the war. However, during the war (1992-1995), measurements were only performed at the Institute and they focused on the concentration of $\mathrm{SO}_{2}$ and the quantities of TSPs and SD, with no chemical analyses. Since 2006, measurements have continued, but to a smaller extent compared to the pre-war period.

In this paper three periods are considered: 1) the period of intensive work of Steel Works Zenica (up to 1992), when it produced two million tons of steel annually; 2) the period characterised by an interruption of integral production (the period between 2006, when air quality measurements were again performed, and 2008 when integral production in Steel Works was re-launched); and 3) the period from 2008 until the end of 2010 when integral production reached its planned capacity of 800000 tons of steel per year.

\section{MATERIALS AND METHODS}

The measurement of the concentration of total suspended particles (24-hour samples) was performed according to guidelines VDI 2463, Blatt 4. Samples were collected in two locations using the sample device Lib Filter Gerath.

Measurements of sediment dust (monthly samples) were performed according to Bergerhoff method. Samples were collected in nine locations using the sample device. Measurement locations are shown in Figure 1.

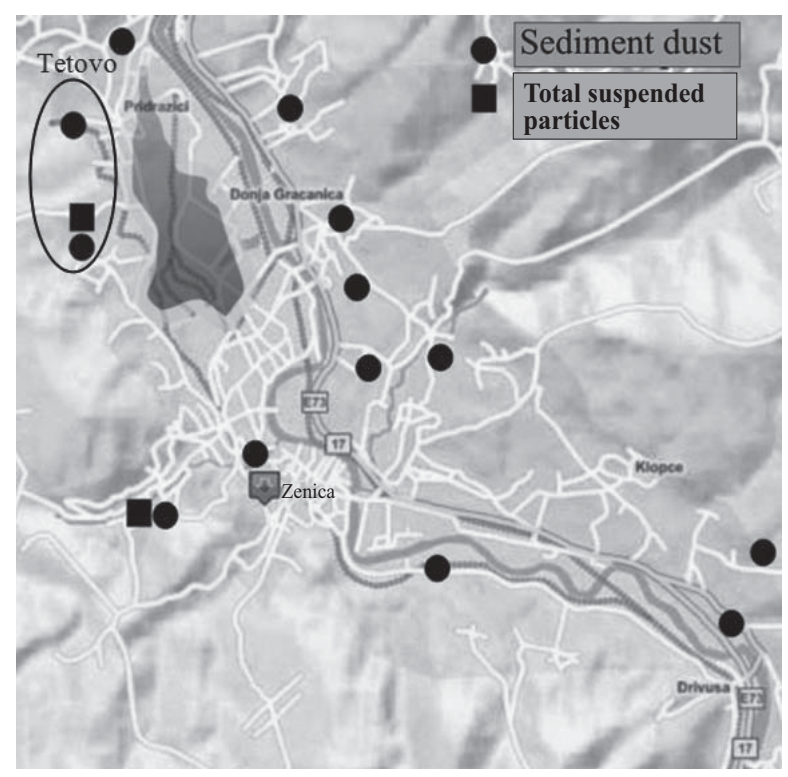

Figure 1 Measurement sites in Zenica city 
The analysis of the composition of total suspended particles and sediment dust was performed using standard PERKING ELMER Analytical Methods for Atomic Absorption Spectrometry in the chemical laboratory of the Metallurgical Institute.

All data concerning TSPs, SD, and the content of toxic metals are the outcome of measurements of the Metallurgical Institute "Kemal Kapetanović" Zenica.

\section{RESULTS AND DISCUSSION}

Annual averages of total suspended particles are shown in Figure 2. It is evident that the amount of TSPs significantly reduced after Steel Works closed its integral production. After re-launching the production, there was no significant increase of TSPs. A reason for such a small increase of TSPs is the ore which is used in the production process, as it was the only thing that was changed in the production process. It can be also noticed that in the period without integral production in Steel Works Zenica, the concentrations of TSPs at both measurement sites were almost identical, which was not the case for the period before 1990. Comparing the period of integral production shutdown and the period with intense production before 1990 , it can be said that $50 \%$ to $60 \%$ of total suspended particles in the city came from Steel Works. It is also noticeable that the concentration of TSPs at the measuring site "Tetovo", which is located near the Steel Works, was constantly higher by about $40 \%$ than the concentration at the measuring site "Institute", which is located in the city. Higher concentration of TSPs at the measuring site near Steel Works means that TSPs consist of heavy particles which can not be easily transported long distances. This could be the reason for the $300 \%$ higher TSP concentration at "Tetovo" compared to the period with no integral production at Steel Works. After the re-launch of integral production in Steel Works, TSPs increased at both measuring sites, "Institute" and "Tetovo". The measuring site "Institute" is located in the city, but its location is in the path of a northern wind, which blows

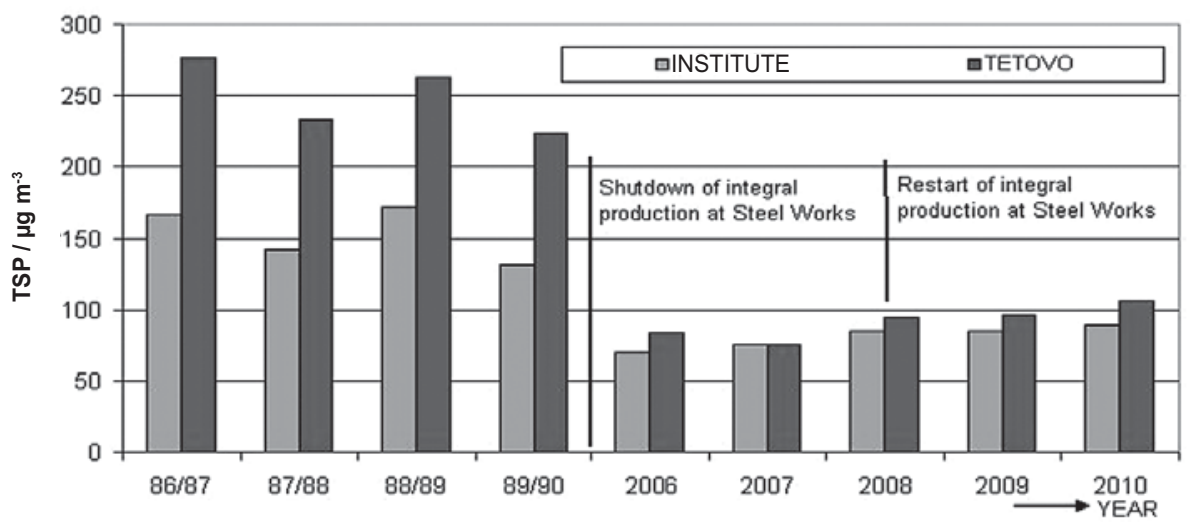

Figure 2 Annual average of total suspended particles (TSPS)

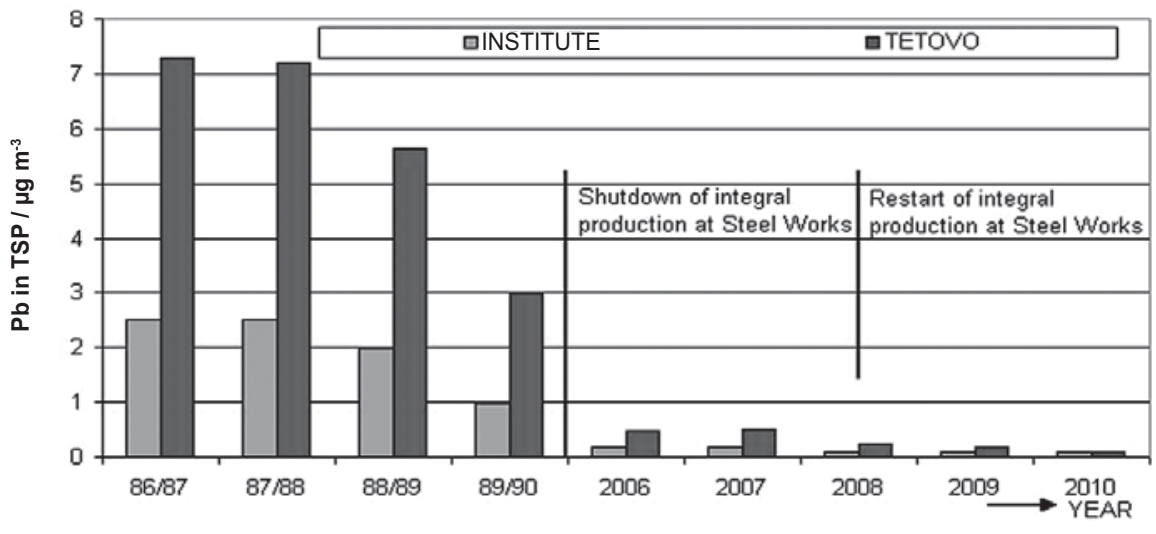

Figure 3 Amount of lead (Pb) in total suspended particles (TSPS) 


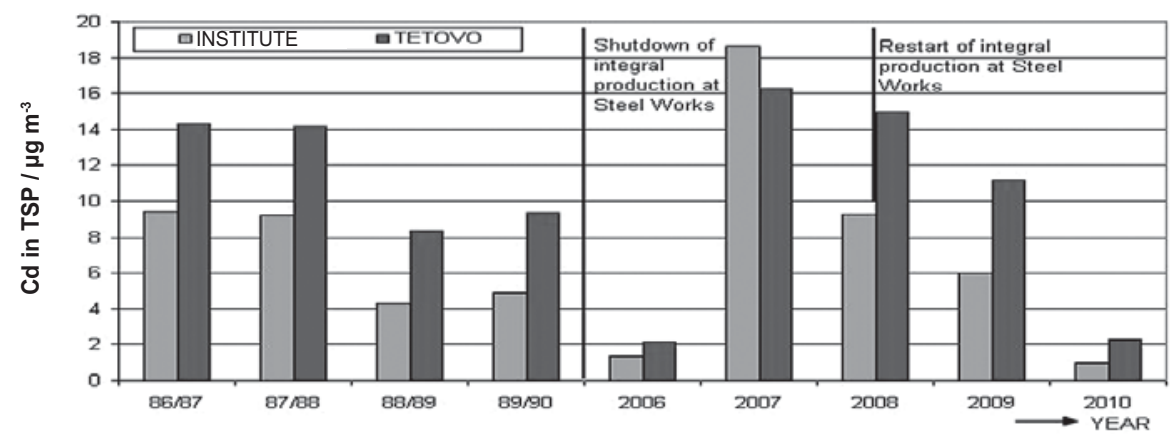

Figure 4 Amount of cadmium (Cd) in total suspended particles (TSPS)

over Steel Works Zenica towards the city and which according to the wind rose blows $14 \%$ of the time. This is the reason why the measuring site "Institute" was taken as a reference point for the city. If the concentration of pollutants is high at this site, their concentration is also high in the city.

Figures 3,4 , and 5 show the concentrations of lead, cadmium, and iron in total suspended particles.

In the period before 1990, when Steel Works Zenica was producing two million tons of primary products, the amount of iron, lead, and cadmium in total suspended particles and sediment dust was much higher than in the post-war period. In the measuring location "Tetovo", annual average concentration of lead in total suspended particles for the period April 1986 - March 1987 was $7.3 \mu \mathrm{g} \mathrm{m}^{-3}$ (limit value is $\left.2 \mu \mathrm{g} \mathrm{m}^{-3}\right)$. The reason for this high value was an ore from the mine Vareš which contained high concentration of lead (average value of $\mathrm{Pb} 0.12 \%$ ) (5). Because of these high concentrations of lead in the ore blast furnace, Steel Works Zenica produced a considerable amount of lead as a by-product.
It can be seen from Figures 3 and 5 that concentrations of lead and iron in total suspended particles decreased significantly after the integral production in Steel Works Zenica was shut down. In this period, lead concentration in TSPs was 15 times lower than in the period of integral production, with a decreasing tendency even in the period after 2008, when integral production was re-launched and when the concentration of TSPs rose. Less lead in the ore used for the production process is connected with less lead in total suspended particles. The concentration of iron in TSPs also decreased by 15 times after the integral production was closed. Once integral production was re-launched, iron in TSPs increased by about 4 times. This increase points to the extent of the impact of Steel Works on the pollution in the city; as for the present level of production, the concentrations of TSPs are 3 to 5 times higher on both measuring sites than before integral production re-start (Figure $5)$.

Figure 4 shows that concentration of cadmium in TSPs significantly decreased after integral production

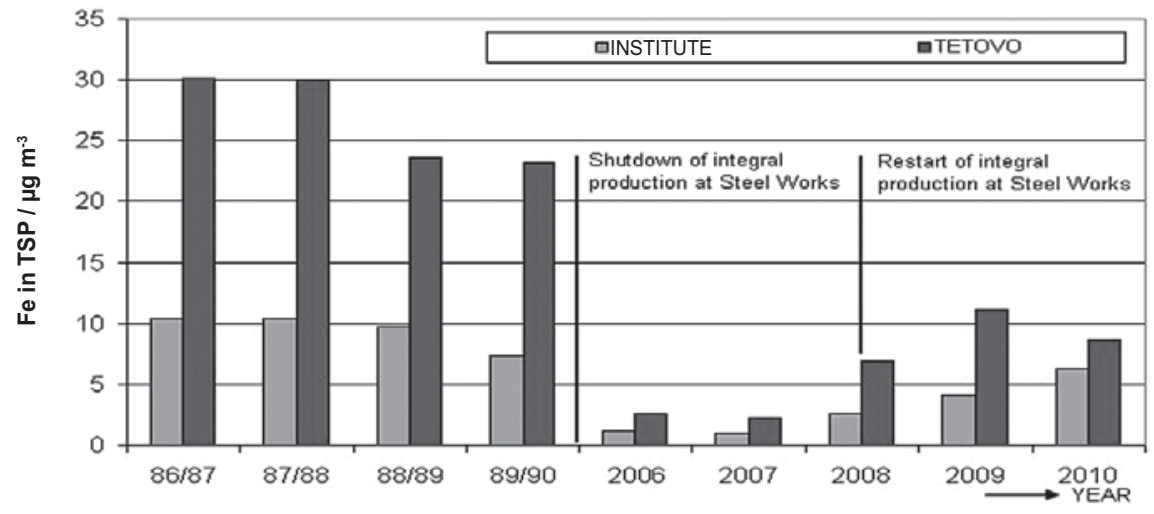

Figure 5 Amount of iron ( $\mathrm{Fe}$ ) in total suspended particles (TSPs) 
had been interrupted. However, the amount of cadmium in TSPs in 2007 was higher than in the period before 1990. High level of cadmium is connected with the production of steel in electric arc furnace 100 tons (EAF 100 tons). It is not known which components are used to produce steel in electric arc furnace 100 tons, but it is noticeable that the concentration of cadmium began to subside as the amount of steel produced in EAF decreased. As it can be seen from Figures 4 and 7, the concentration of cadmium after 2007 reduced in TSPs but at a slower pace than in SD. The probable reason for this is a bag filter installed on EAF 100 tons through which only fine particles can escape. Fine particles are dispersed on greater surfaces so they have more impact on TSPs and less on SD. The amount of cadmium determined in 2007 in the measuring location "Institute" is the highest amount measured for all three analysed periods. We speculate that this extra amount of cadmium could have come from two foundries located in the city.

Average concentration of sediment dust (SD) is shown in Figure 6. After Steel Works' integral production was brought to a standstill, a significant decrease of SD was noticed, especially in measuring locations near Steel Works ("Tetovo"), because dust emitted from Steel Works consisted mostly of heavy fractions which could not be transported long distances. Shutting integral production down resulted in identical sediment dust values in all locations, whereas the subsequent restarting of integral production raised the concentrations mostly on sites near Steel Works Zenica.

In the period 1986-1990, the amount of lead and cadmium in sediment dust was very high and there was almost no area in Zenica valley with concentrations of lead and cadmium in SD below the limits for vegetation (except for vegetation with roots) (2).

Annual average cadmium in sediment dust can be seen in Figure 7. The amount of cadmium in SD decreased significantly with the shutdown of integral production in Steel Works, and then gradually even more so when the production subsided. The increase in the amount of cadmium in SD in 2007, as was the case with TSPs, is connected with 100 tons electric furnace. With its shutdown by the end of 2009, when basic oxygen furnace yielded its planned capacity, concentrations decreased significantly. The amount of iron in sediment dust was not subjected to analysis because limit values do not exist. The amount of iron in total suspended particle was measured in order to

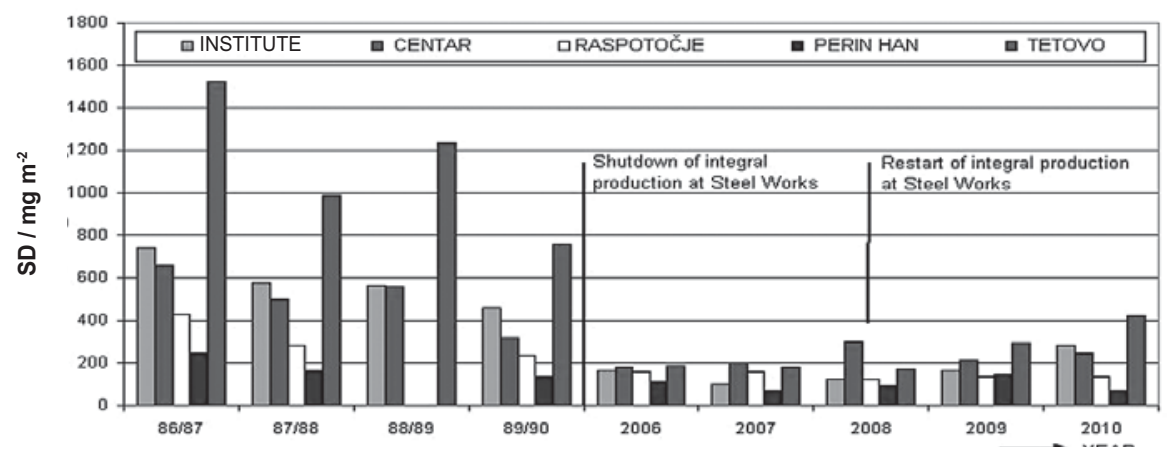

Figure 6 Annual average of sediment dust (SD)

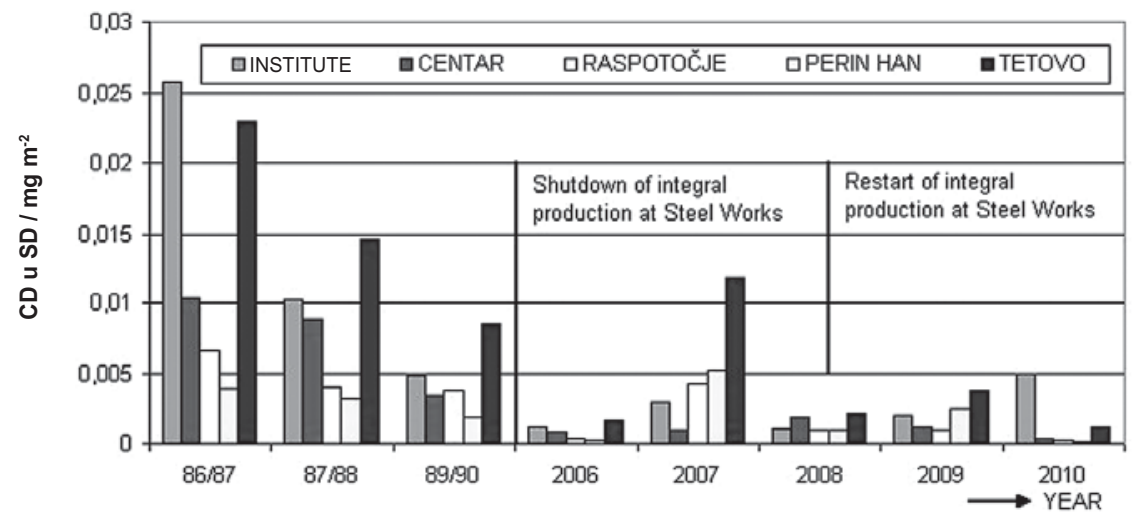

Figure 7 Amount of cadmium (Cd) in sediment dust (SD) 


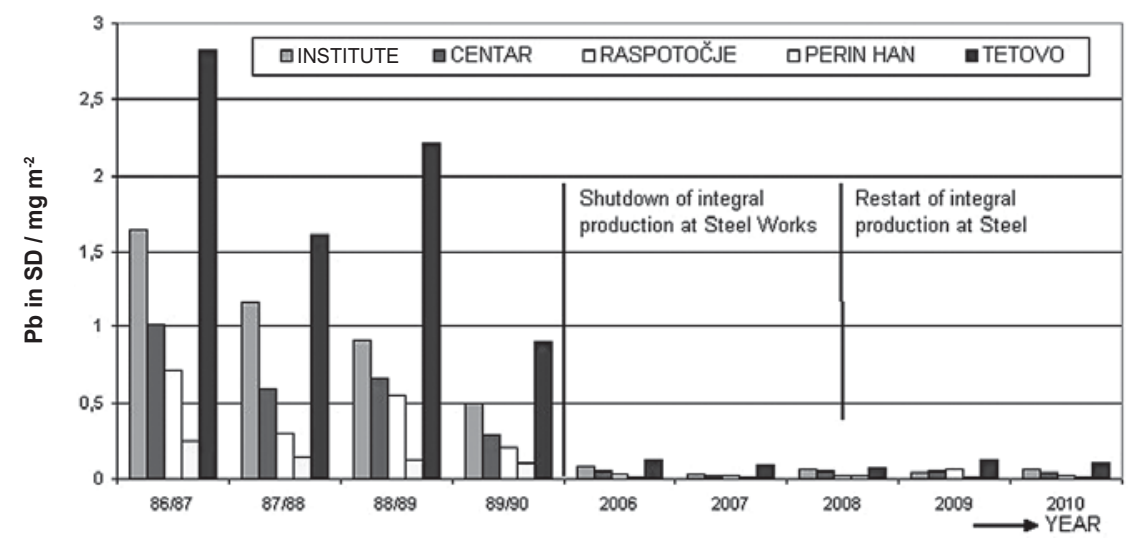

Figure 8 Amount of lead $(\mathrm{Pb})$ in sediment dust (SD)

monitor the impact of Steel Works Zenica on environmental pollution.

The analysis of soil from the areas near Steel Works (in 2009), performed by the Federal Institute for Agropedology, showed that soil was contaminated with toxic metals, especially with lead, zinc, nickel, chrome, and cadmium $(8,11)$. Concentrations of these elements were several times higher than limit values. Toxic elements in soil accumulate in plants, which is then detrimental for both humans and animals (9, 11).

Ten years after integral production had been shut down (in 1999), the amount of toxic metals in soil in the area around Steel Works (6) was smaller than in the period before shutdown. This is the result of a long period of shutdown, during which these metals were transported from soil by the plants and washed out with water (6). Soil analysis performed in 2009 by the Federal Institute for Agropedology in the same areas around Steel Works showed that concentrations of lead and cadmium were higher than in 1989, and the immission values of toxic metals were much lower (8). This calls for an additional analysis of possible sources of toxic metals. Industrial and communal waste disposal sites, containing all kinds of wastes that are disposed of without any control, are located in the proximity of the examined areas. The communal disposal site is now closed but is still active, and uncontrolled fires break out there quite often. In the past ten years, the industrial waste disposal site has been intensively dug around in search for scrap iron and coal.

Irrespective of reduced concentrations of metals in SD and TSPs, the amount of metals in soil is still beyond limit values $(8,11)$. This means that we are still paying the price for having polluted the soil in the period when Steel Works was producing two million tons of steel, and for having allowed uncontrolled disposal of industrial and communal waste in the most polluted part of the city.

\section{CONCLUSION}

On the basis of the analyses for the presence of lead, cadmium, and iron in sediment dust and total suspended particles before and after integral production in Steel Works Zenica, the following conclusions can be derived:

- Air quality assessed by the amount of metals in total suspended particles and sediment dust in the city of Zenica was poorer when Steel Works was producing two million tons of steel annually.

- When metals are considered, most contaminated locations are those surrounding Steel Works Zenica.

- Integral production shutdown in Steel Works caused a significant drop of SD, TSPs, and the amount of metals in them.

- Restart of integral production did not cause a considerable increase in SD and TSPs. The concentration of iron augmented, lead remained at the same level as before the re-start of integral production, cadmium reached a level higher than where it was in the period in which Steel Works produced two million tons of steel annually.

- Comparing the results of soil analyses from the areas near Steel Works, which were performed in 2009, and those from 1990, it is clear that soil was more contaminated with toxic metals, especially with lead, 
zinc, nickel, chrome, and cadmium in 2009 when the immisson values of toxic meals were significantly lower than in 1990 .

\section{REFERENCES}

1. Duran F, Arnautović Z, Galijašević D. Stanje zagađenosti zraka u Zenici [Situation with air quality in Zenica, in Bosnian/Serbian/Croatian]. In: Zbornik referata Jedinstvena jugoslavenska strategija očuvanja čistoće vazduha / Prvi jugoslavenski kongres o očuvanju čistoće vazduha. Knjiga II; 14-16 June1989. Zenica, BiH. Zenica: Metalurški institut "Hasan Brkić"; 1989, p. 962-91.

2. Duran F. Specific characteristics of air quality in Zenica over ten-year period 1986-1996. In: Šega K, Fugaš M, Vančina F, editors. Proceedings of the First Croatian Scientific and Professional Assembly “Air Protection '97”; 16-18 October 1997; Crikvenica, Croatia. Zagreb: Croatian Air Pollution Prevention Association; 1997. p. 153-9.

3. Izvještaji o zagađenosti zraka u gradu Zenica za posmatrane periode [Reports of Air Pollution in Zenica for Considered Periods, in Bosnian/Serbian/Croatian]. Metalurški institut "Kemal Kapetanović" Zenica, Zenica 1986-2010.

4. Studija uticaja glavnih izvora $\mathrm{SO}_{2}$ na aerozagađanje u Zenici [Study of impact of main sources $\mathrm{SO}_{2}$ emission on air pollution in Zenica, in Bosnian/Serbian/Croatian]. Zagreb: Republički hidrometeorološki zavod Hrvatske; 1987.

5. RMK Zenica and Bethlehem International Engineering Corporation. Technical Design for Pollution Abatement at Iron and Steel Works Zenica. Zenica: RMK Zenica, BIEC; 1984.
6. Goletić Š. Teški metali u okolišu. Zenica: Mašinski fakultet Univerziteta u Zenici; 2005.

7. Goletić Š, Bukalo E, Trako E. Monitoring the content of heavy metals in soil and plants in environment in ironworks Zenica. In: Ekinović S, editor. Proceedings of the $7^{\text {th }}$ Reasrch/ Expert Conference with International Participation "Quality 2011"; 1-4 June 2011. Neum, Bosnia and Herzegovina. Zenica: Faculty of Mechanical Engineering in Zenica; 2011. p. 743-8.

8. Trako E, Bukalo E, Ramović M, Latinović E, Salčinović A, Semić M, Mitrović M. Elaborat o zagađenosti zemljišta neorganskim i organskim polutantima na području Općine Zenica, Elaborat [Monitoring of soil pollution with inorganic and organic pollutants on area of Zenica municipality, in Bosnian/Serbian/Croatian]. Zenica: Federalni zavod za agropedologiju; 2010.

9. Trako E, Bukalo E, Ramović M, Latinović E, Salčinović A, Semić M, Mitrović M. Prisustvo neorganskih polutanata u nekim biljnim kulturama na području općine Zenica, Elaborat [Monitoring of inorganic pollutants in certain plants on area of Zenica municipality, in Bosnian/Serbian/Croatian]. Zenica: Federalni zavod za agropedologiju; 2010.

10. Pravilink o graničnim vrijednostima kvaliteta zraka [Regulation on limit values for air quality, in Bosnian/ Serbian/Croatian]. Službene novine Federacije Bosne i Hercegovine 12/2005.

11. Pravilnik o utvrđivanju dozvoljenih količina štetnih i opasnih materija u zemljištu i metode njihovog ispitivanja [Regulation on permitted values of harmful and dangerous goods in soil and methods for their determination, in Bosnian/Serbian/ Croatian]. Službene novine Federacije Bosne i Hercegovine $72 / 2009$. 


\section{Sažetak}

SADRŽAJ OLOVA, KADMIJA I ŽELJEZA U TALOŽNOM PRAHU I UKUPNIM LEBDEĆIM ČESTICAMA PRIJE I NAKON POKRETANJA INTEGRALNE PROIZVODNJE U ŽELJEZARI ZENICA

Opće je poznato da sredine s baznom industrijom imaju lošu kvalitetu zraka. Zenica kao centar crne metalurgije bivše Jugoslavije pripada najzagađenijim gradovima. Onečišćenje zraka dosegnulo je vrhunac 1987. godine kada su prosječne koncentracije bile izrazito visoke (npr. koncentracija SO bila je oko 1800 $\mu \mathrm{g} \mathrm{m}^{-3}$ ). Početkom rata integralna željezara je prestala s radom, ali je 2008. godine ponovno pokrenuta integralna proizvodnja u željazari. U ovom radu je prikazana analiza sadržaja olova, kadmija i željeza u taložnom prahu i lebdećim česticama za razdoblja prije pokretanja integralne proizvodnje u Željezari Zenica, danas, Arcelor Mittal Zenica, i poslije pokretanja te proizvodnje. Norme za sadržaj željeza ne postoje, ali se njegova koncentracija u lebdećim česticama i taložnom prahu u Zenici određuje već 28 godina, upravo zbog željezare. Sadržaj olova i kadmija se također određuje jer su ta dva elementa, a naročito olovo, dosta prisutni u zeničkoj kotlini. U radu je prikazan sadržaj navedenih elemenata u taložnom prahu i lebdećim česticama prije pokretanja integralne proizvodnje u željezari i poslije toga. Mjerenje ukupnih lebdećih čestica obavlja se na dva mjesta a prema VDI 2463 Blatt 4. Taložni prah se određuje prema metodi Bergerhoffa na 9 mjernih mjesta, a određivanje sadržaja željeza, olova i kadmija vršeno je standardnim metodama u kemijskom laboratoriju Metalurškog instituta "Kemal Kapetanović” u Zenici. Povećan sadržaj ovih parametara u vrijeme rada integralne proizvodnje u Željezari u odnosu na period njezinoga mirovanja, jasno pokazuje utjecaj na kvalitetu zraka zeničke kotline.

KLJUČNE RIJEČI: onečišćenje zraka, atmosferska prašina, temperaturna inverzija, Zenica

\section{CORRESPONDING AUTHOR:}

Halim Prcanović, BSc

Metalurški institut Kemal Kapetanović Zenica,

Univerzitet u Zenici

Zavod za zaštitu i ekologiju

Zenica, Bosnia and Herzegovina

E-mail:halim.p@bih.net.ba 